\title{
Cross-generational feeding of $B t$ (Bacillus thuringiensis)-maize to zebrafish (Danio rerio) showed no adverse effects on the parental or offspring generations
}

\author{
Monica Sanden ${ }^{1 *}$, Robin Ornsrud ${ }^{1}$, Nini H. Sissener ${ }^{1}$, Susanne Jorgensen ${ }^{1}$, Jinni $\mathrm{Gu}^{2}$, \\ Anne Marie Bakke ${ }^{2}$ and Gro-Ingunn Hemre ${ }^{1}$ \\ ${ }^{1}$ National Institute of Nutrition and Seafood Research (NIFES), PO Box 2029, Nordnes, 5817 Bergen, Norway \\ ${ }^{2}$ Department of Basic Sciences and Aquatic Medicine, Aquaculture Protein Centre (a CoE), Norwegian School \\ of Veterinary Science, PO Box 8146 Dep, N-O033 Oslo, Norway
}

(Submitted 2 January 2013 - Final revision received 29 April 2013 - Accepted 1 May 2013 - First published online 17 June 2013)

\begin{abstract}
In the present study, zebrafish (Danio rerio) were fed casein/gelatin-based diets containing either 19\% Bt (Bacillus thuringiensis)-maize or its parental non- $B t(n B t)$-maize control for two generations (F0: sixty fish; F1: forty-two to seventy fish per treatment). The study focused on growth and reproductive performance, liver CuZn superoxide dismutase (SOD) enzyme activity, gene transcript levels targeting important cellular pathways in the liver and mid-intestine, histomorphological evaluation of the intestine, differential leucocyte counts, offspring larva swimming activity and global DNA methylation in offspring embryos. No significant effects were observed in the parental generation. The offspring were either fed the same diets as those fed to their parents ( $B t-B t$ or $n B t-n B t$ ) or switched from the $B t$ diet to the $n B t$ diet $(B t-n B t)$. The $B t-B t$ offspring exhibited a significantly higher body mass increase, specific growth rate and feed utilisation than fish fed the $n B t-n B t$ diet and/or fish fed the $B t-n B t$ diet. Liver and mid-intestinal gene transcript levels of CuZn SOD were significantly higher in fish fed the $n B t-n B t$ diet than in those fed the $B t-B t$ diet. Liver gene transcript levels of caspase 6 were significantly lower for the $n B t-n B t$ group than for the $B t-B t$ group. Overall, enhanced growth performance was observed in fish fed the $B t$ diet for two generations than in those fed the $n B t$ diet for one and two generations. Effects observed on gene biomarkers for oxidative stress and the cell cycle (apoptosis) may be related to the contamination of $n B t$-maize with fumonisin B1 and aflatoxin B1. In conclusion, it is suggested that $B t$-maize is as safe and nutritious as its $n B t$ control when fed to zebrafish for two generations.
\end{abstract}

Key words: Cry1Ab (crystal protein 1Ab): Generational studies: Performance: Reproduction

Potential health and environmental risks of GM crops are still being debated about in Norway and other European countries. Some uncertainty is linked to the ingestion of GM plants modified to express insecticidal Bt (Bacillus thuringiensis) toxins, also known as Cry proteins, due to their potential adjuvant properties ${ }^{(1)}$. These proteins are naturally produced by the spore-forming soil bacterium $B$. thuringiensis. In targeted insects, the different Cry proteins bind to specific receptors in the mid-intestine and cause damage to the intestinal wall by forming pores, thus changing the permeability of epithelial cells and eventually resulting in death ${ }^{(2)}$. The Norwegian Scientific Committee for Food Safety has questioned the safety of $B t$-toxins and identified knowledge gaps ${ }^{(3)}$. It may be premature to accept that the detrimental effects are limited to the targeted organisms only ${ }^{(4)}$. The first line of defence when an organism is exposed to a potential toxicant via feed is the barrier of the intestinal tract. In the present study, we measured several intestinal biomarkers at the gene transcript level including a thorough histological evaluation. The gene transcripts covered important cellular pathways and intestinal functions including gene transcripts linked to the digestion of starch and absorption of glucose, appetite control, cellular DNA repair, oxidative stress and apoptosis. To further investigate possible mechanisms of effects, global DNA methylation was investigated in embryos. It was hypothesised that the crystal protein $1 \mathrm{Ab}$ (Cry1Ab) protein or other factors in $B t$-maize could affect the methylation either directly or indirectly by inhibition of nutrient uptake.

Abbreviations: AFLB1, aflatoxin B1; Bt, Bacillus thuringiensis; CF, condition factor; Cry1Ab, crystal protein 1Ab; DON, deoxynivalenol; dph, day post-hatch; EFSA, European Food Safety Authority; F0, parental generation; F1, offspring generation; FB1, fumonisin B1; FCR, feed conversion ratio; $n B t$, non-Bacillus thuringiensis; SOD, superoxide dismutase.

*Corresponding author: M. Sanden, fax +475590529, email monica.sanden@nifes.no 
MON810 is one of several modification events producing $B t$-maize and has a gene introduced encoding the Cry $1 \mathrm{Ab}$ protein $^{(5)}$. Numerous studies have investigated $B t$-maize in terrestrial animal feeds, but few studies have focused on $B t$-maize as an ingredient in fish feeds. A recent review has summarised results from fish feeding trials with GM products, including $B t$-maize ${ }^{(6)}$. Increased feed consumption resulting in increased growth has been observed in a short-term feeding study with zebrafish fed $B t$-maize ${ }^{(7)}$. On the other hand, Atlantic salmon post-smolt fed Bt-maize at 15 and $30 \%$ of the total diet exhibited significantly reduced feed intake, growth rate and final weight than those fed non-Bt-maize (near-isogenic line) $)^{(8,9)}$, as well as indications of stress and immune responses ${ }^{(9)}$. However, a recent Atlantic salmon study has not confirmed the earlier results of reduced growth ${ }^{(10)}$.

A long-term study with Atlantic salmon fed $12 \%$ Bt-maize has not revealed obvious pathological effects, but indicated changes in plasma TAG levels, intestinal cell proliferation and intestinal glucose uptake ${ }^{(11,12)}$. Thus, uncertainties still remain regarding the safety of MON810 maize in diets used for cultivated fish. Confounding factors in the two maize types used in fish feeds, such as varying levels of mycotoxins ${ }^{(13)}$, may be a source of the inconsistent findings between feeding trials using the same $B t$-maize event. When measured in the above-mentioned feeding trials, including in the present trials, differences in mycotoxin types (deoxynivalenol (DON), fumonisin B1 (FB1) and aflatoxin B1 (AFLB1)) were observed. Information on the absorption and toxicokinetics of mycotoxins in farmed finfish species is limited, and little or no information is available on the carry-over of dietary mycotoxins from the feed to fish. Limited amounts of data exist on its potential effect on the methylation of DNA ${ }^{(14)}$. The European Food Safety Authority (EFSA) has made an evaluation of DON as a contaminant in animal feeds, but concluded that no safe level could be established based on the available database (EFSA 2004). Although there is no general consensus on how and when feeding trials should be performed in safety assessments of GM plants ${ }^{(15)}$, longer-term studies and generational studies are recommended, particularly where the mode of action of the novel protein or possible unintended effects of the genetic modification are unclear. The EFSA has pointed out that in some cases where the effects of individual substances are not known, longerterm studies with emphasis on reproduction/development should be considered and may be more sensitive than subchronic endpoints ${ }^{(16)}$. This has been further emphasised in a recent review by Snell et al. ${ }^{(17)}$. Longer-term or generational studies are also repeatedly requested by researchers when the effects of GM feeds are identified, but they are struggling to interpret the biological significance due to the limited duration of the studies. Zebrafish has previously been suggested as a model for aquaculture species in the evaluation of GM plant feed ingredients $^{(7)}$, although it has been recognised that it is less sensitive to certain feed toxicants than, for example, Atlantic salmon and rainbow trout ${ }^{(14)}$. In the study by Sanden et al. ${ }^{(14)}$, zebrafish was not found to be an appropriate model when evaluating the effects of contaminated aquaculture feeds on parameters such as growth performance and feed and nutrient utilisation. It may, however, be an adequate aquaculture model when studying the mode of action of various feed ingredients and feed contaminants. In the present study, the generational effects of $B t$-maize feeding were investigated. The aim was to investigate (1) the dietary effects of $B t$-maize in the parental generation, with a focus on growth and reproductive performance, health parameters and gene transcript biomarkers, and (2) the effects of dietary $B t$-maize fed to the parental generation and their offspring, with a focus on one epigenetic marker, larva swimming activity, growth performance and histomorphological evaluation of the intestine, as well as gene transcript biomarkers.

\section{Materials and methods}

\section{Diets and feed production}

Two casein/gelatin-purified diets were prepared at our laboratory. Table 1 summarises the ingredients used, proximate composition, and mycotoxin and pesticide content. Seeds from maize MON $810(B t)$ and the unmodified parent line $(n B t)$ (PR34N44 and PR34N43, respectively; Pioneer HiBred) were grown simultaneously in neighbouring fields in 2007 in Valtierra, Navarra, Spain. These two maize lines have been thoroughly described by Walsh et al. ${ }^{(18)}$ and reported to have only minor differences in proximate and nutrient composition. The preparation of diets involved mixing three different fractions. Gelatin and carophyll pink were dissolved in hot water, at a 9:1 ratio (hot water (about $80^{\circ} \mathrm{C}$ )-gelatin, w/w), before all the dry ingredients and the oil mixture were carefully added. The blend was mixed in a conventional food processor until becoming homogenous. The paste was poured onto labelled parchment-covered trays and then dried overnight at low temperatures $\left(40^{\circ} \mathrm{C}\right)$ in an oven, before grinding, sieving and storing at $-18^{\circ} \mathrm{C}$. The same diets were fed to the parental generation (F0) and offspring generation (F1).

\section{Diet chemical analysis}

Moisture in the diets was measured by drying at $103^{\circ} \mathrm{C}$ for $24 \mathrm{~h}$, ash was weighed after burning at $540^{\circ} \mathrm{C}$, and lipid content was measured after extraction with ethyl acetate ${ }^{(19)}$. $\mathrm{N}$ content was measured using a nitrogen determinator (LECO FP-428; LECO Corporation) according to the AOAC (Association of Analytical Communities) official methods of analysis, and crude protein content was calculated as $\mathrm{N} \times 6 \cdot 25$. Starch content was measured by enzymatic degradation as described by Hemre et al. ${ }^{(20)}$. Mycotoxin levels in the experimental diets were analysed by the Norwegian Veterinary Institute by $\mathrm{GC}-\mathrm{MS}^{(21)}$. The content of Cry1 $\mathrm{Ab}$ in the diets was tested using a commercially available qualitative Bt-Cry1Ab/1Ac ELISA kit (Agdia Biofords). The diets were analysed for pesticide residues by testing against a panel of more than 300 different active substances (BioForsk, Norwegian Institute for Agricultural and Environmental Research, Ås, Norway).

\section{Fish husbandry and experimental design}

The trials were conducted in accordance with the Norwegian Animal Welfare Act no. 73 of 20 December 1974 and the 
Table 1. Formulation and proximate composition of the experimental diets including the content of mycotoxins, the presence of the crystal protein $1 \mathrm{Ab}(\mathrm{Cry} 1 \mathrm{Ab})$ protein and pesticide residues

\begin{tabular}{|c|c|c|}
\hline & $n B t$-maize & Bt-maize \\
\hline \multicolumn{3}{|l|}{ Formulation (\%) } \\
\hline Casein sodium salt & 40 & 40 \\
\hline Gelatin & 12 & 12 \\
\hline Cod-liver oil & 3 & 3 \\
\hline Rapeseed oil & 9 & 9 \\
\hline Dextrin & 4 & 4 \\
\hline$\alpha$-Cellulose & 3 & 3 \\
\hline Lecithin & 2 & 2 \\
\hline Minerals* & 5 & 5 \\
\hline Vitaminst & 1 & 1 \\
\hline AA mix $\ddagger$ & 1 & 1 \\
\hline Carophyll pink 8\% & 1 & 1 \\
\hline Maize & 19 & 19 \\
\hline \multicolumn{3}{|l|}{ Proximate analysis (\%) } \\
\hline DM & 88 & 88 \\
\hline Protein & 49 & 49 \\
\hline Lipids & 12 & 12 \\
\hline Starch & 17 & 17 \\
\hline Ash & 5 & 5 \\
\hline Rest & 5 & 5 \\
\hline \multicolumn{3}{|l|}{ Mycotoxins $(\mu \mathrm{g} / \mathrm{kg}) \S$} \\
\hline DON & $<10$ & 154 \\
\hline Zearalenone & $<3$ & $<3$ \\
\hline NIV & $<10$ & $<10$ \\
\hline Aflatoxin B1 & 0.4 & $<0.1$ \\
\hline Aflatoxin B2 & $<0.1$ & $<0.1$ \\
\hline Fumonisin B1 & 23 & $<10$ \\
\hline Fumonisin B2 & $<10$ & $<10$ \\
\hline Fumonisin B3 & $<10$ & $<10$ \\
\hline \multicolumn{3}{|l|}{ Transgenic protein } \\
\hline Cry1 $A b$ & Negative & Positive \\
\hline \multicolumn{3}{|l|}{ Pesticide (mg/kg)\| } \\
\hline Diphenylamine & 0.03 & 0.05 \\
\hline
\end{tabular}

$n B t$, non-Bacillus thuringiensis; Bt, Bacillus thuringiensis; AA, amino acids; DON, deoxynivalenol; NIV, Nivalenol.

* $60 \%$ Dicalcium phosphate dehydrate, $0.01 \%$ cobalt chloride hexahydrate, $0.04 \%$ copper sulphate, $30 \%$ potassium sulphate, $0.1 \%$ potassium iodide, $2 \%$ magnesium sulphate heptahydrate, $0.1 \%$ manganese sulphate, $5.75 \% \mathrm{NaCl}, 0.01 \%$ sodium selenite, $1 \%$ zinc sulphate heptahydrate, and $1 \%$ iron sulphate heptahydrate.

† $0.1 \%$ Vitamin $A, 0.04 \%$ vitamin $D_{3}, 2 \%$ vitamin $E, 0.1 \%$ vitamin $K, 4.3 \%$ vitamin C, $40 \%$ choline, $0.15 \%$ thiamin, $0.19 \%$ riboflavin, $0.2 \%$ pyridoxine, $2 \%$ niacin $4 \%$ inositol, $0.07 \%$ folic acid, $0.6 \%$ calcium pantothenate, $0.75 \%$ biotin, $0.3 \%$ cobalamin and $45.2 \%$ casein salt.

$¥ 4.3 \%$ Taurine, $21.4 \%$ aspartic acid, $6.4 \%$ threonine, $8.5 \%$ glycine, $15.2 \%$ alanine, $4.3 \%$ valine, $5.8 \%$ methionine, $4.3 \%$ isoleucine, $8.5 \%$ leucine, $6.4 \%$ lysine, $8.5 \%$ arginine and $6.4 \%$ tryphtophan.

$\S$ Mycotoxin content in the feed is calculated based on the levels found in the ingredients. Mycotoxins below the detection limit: diacetoxyscirpenol $<10 \mu \mathrm{g} / \mathrm{kg}$ 3-acetyldeoxynivalenol $<10 \mu \mathrm{g} / \mathrm{kg}$; 15-acetyldeoxynivalenol $<10 \mu \mathrm{g} / \mathrm{kg}$; T2 toxin and HT2 toxin $<10 \mu \mathrm{g} / \mathrm{kg}$; aflatoxin G1 $<0.1 \mu \mathrm{g} / \mathrm{kg}$; aflatoxin $\mathrm{G} 2<0.1 \mu \mathrm{g} / \mathrm{kg}$

$\|$ An array of more than 300 pesticides were analysed in the two diets (Bioforsk), and only diphenylamine was detected above the limit of quantification.

Regulation on Animal Experimentation of 15 January 1996. The experiments were run in an AHAB multiple rack zebrafish system (Aquatic habitats, Aquatic Eco-Systems) with reverse osmosis followed by automatic salt dosing of the water, UV, and mechanical and carbon filtration of the water. During the trials, the temperature was $28.5 \pm 0.5^{\circ} \mathrm{C}$, salinity was $500 \pm 30 \mu \mathrm{S} / \mathrm{cm}$, oxygen was $>90 \%$ saturation, photoperiod was $14 \mathrm{~h}$ light $-10 \mathrm{~h}$ dark with lights on from 22.00 to 08.00 hours. Larvae were fed ad libitum with Artemia nauplii for 1 month before starting the parental feeding trial (F0) on 7 February 2011. In this trial, 120 zebrafish larvae $(35 \mathrm{~d}$ post-hatch, dph) were distributed into six tanks (3.0 litres, $n$ 3) and randomly assigned to one of the following two diets: $B t$-maize diet and $n B t$-maize diet. The offspring feeding trial (F1) was started on 3 October 2011 in which 168 zebrafish larvae (39 dph) obtained from the parental generation (fourth spawning) were distributed into twelve tanks (3.0 litres) and fed one of the following three regimens: $B t$-maize diet $B t-B t$ (larvae from the $B t$-maize diet-fed parental generation, $n$ 4); $n B t$-maize diet $B t-n B t$ (larvae from the $B t$-maize diet-fed parental generation, $n 3$ ); $n B t$-maize diet $n B t-n B t$ (larvae from the $n B t$-maize diet-fed parental generation, $n 5$ ). Fig. 1 presents an overview of the experimental design. Mortality was recorded on a daily basis. The parental generation feeding trial (F0) followed a restricted feeding regimen, where feeding was adjusted to the growing biomass in each tank and gradually reduced from 10 to $2-3 \%$ of total biomass during the trial. The offspring generation feeding trial (F1) followed a pair-feeding regimen in which the fish tank that demonstrated the lowest feed intake determined the amount of feed offered to the other tanks. Within both the generations, fish in all tanks were given the same amount of feed twice a day and efforts were made to avoid feed waste by giving small portions. Feed particle size was gradually increased with increasing fish size from $315-400 \mu \mathrm{m}$ up to $560-700 \mu \mathrm{m}$ at the end of the feeding trial.

\section{Tissue sampling - parental generation}

Before handling, all fish were euthanised by immersion in an ice water bath $\left(4^{\circ} \mathrm{C} \text { or less }\right)^{(22)}$. After $45 \mathrm{~d}$ of feeding, fish were sampled on 24 March 2011 ( $80 \mathrm{dph}$ ). Data on fish performance were recorded from seven to ten randomly selected fish per tank. All fish were wet weighed to the nearest $0 \cdot 01 \mathrm{~g}$, total length was determined to the nearest millimetre and sex was recorded. Blood was sampled from three to four fish per tank by cutting off the tail posterior to the anal fin and by collecting the blood into capillary tubes coated with heparin. For differential leucocyte counts, a small droplet of blood was placed at the end of a glass slide to produce smears before being fixed in methanol. The mid-intestine was obtained from four fish per tank and dissected using fine surgical tools under magnification before being quickly frozen in liquid $\mathrm{N}_{2}$ and stored for later RNA extraction and gene expression analysis. All remaining fish were pooled into two experimental tanks (10 litres): $B t$-maize group: twentytwo fish (two females); $n B t$-maize group: sixteen fish (four females), and fed the same experimental feeds for another 6 months (1-2\% of the biomass). Fertilised eggs were collected from the $B t$-maize and $n B t$-maize groups on 23 August and larvae that hatched on 25 August (offspring generation). Data on reproductive performance were collected at the following time points in the pooled tanks: at $175-297 \mathrm{dph}$ for fecundity (seven samplings); at 127-183 dph in fertilised eggs for epigenetics (three samplings); at 274-300 dph in F1 larvae for swimming activity (three samplings). Finally, on 16 November 2011, at day 283 $(317 \mathrm{dph})$, all remaining fish from the parental generation (F0) were sampled and wet weighed to the nearest $0.01 \mathrm{~g}$ 


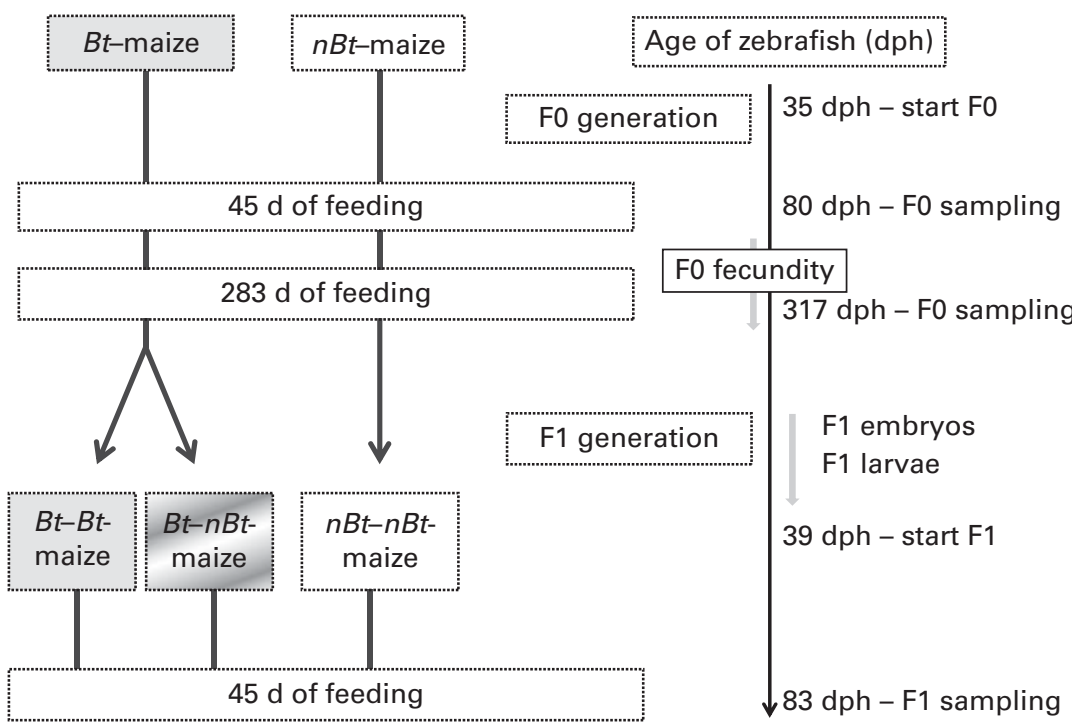

Fig. 1. Overview of the experimental design, time of sampling and age (days post-hatch; dph) of the zebrafish in the feeding trial. The parental zebrafish were fed $B t$ (Bacillus thuringiensis)-maize or $n B t$ (non-Bt)-maize diets $(n 3)$ for 45 and $283 \mathrm{~d}$. The offspring generation $(\mathrm{F} 1)$ were fed the same diets as those fed to their parents, Bt-Bt-maize $(n 4)$ or $n B t-n B t$-maize $(n 5)$, or cross-over Bt-nBt-maize $(n 3)$ for $45 \mathrm{~d}$. Data on parent fish (F0) fecundity were collected between 175 and $300 \mathrm{dph}$. F1 embryos ( $51 \mathrm{~h}$ post-fertilisation) and F1 larvae (4 dph) were collected for epigenetic analysis and swimming activity measurements, respectively.

and total length was determined to the nearest millimetre. Livers were collected from ten fish (F0) per diet and dissected before being quickly frozen in liquid $\mathrm{N}_{2}$ and stored at $-80^{\circ} \mathrm{C}$ for later CuZn superoxide dismutase (SOD) analysis.

\section{Tissue sampling - offspring generation}

The offspring larvae were reared in our laboratory under conditions the same as those described for the parental generation. Embryos ( $51 \mathrm{~h}$ post-fertilisation) were collected for global DNA methylation analysis (F1) and larvae ( $4 \mathrm{dph}$ ) were collected for analysing swimming activity (F1). The methodology used is described below. Before the offspring fish sampling ( $83 \mathrm{dph}$ ), which was performed on 16 November 2011, all fish were euthanised by immersion in an ice water bath $\left(4^{\circ} \mathrm{C} \text { or less }\right)^{(22)}$. Data on fish performance of all fish were recorded (fourteen fish per tank) using a procedure the same as that used for the parental generation, and the liver and midintestine were dissected from six fish as described before, quickly frozen in $\mathrm{N}_{2}$ and stored at $-80^{\circ} \mathrm{C}$ for later gene expression analysis. For histological evaluation, the whole intestinal tract was immediately sampled and placed into standard Bouin's solution. After fixation, the samples were dehydrated in graded series of alcohol, equilibrated in xylene and embedded in paraffin.

\section{RNA isolation and quantitative real-time RT-PCR (parental generation and offspring generation)}

Total RNA was extracted from individual mid-intestinal and liver tissues using the TRIzol reagent according to the manufacturer's instructions (Invitrogen, Life Technologies), and residual genomic DNA was removed by DNase treatment using DNA-free reagents (Ambion). RNA quality and integrity were assessed using NanoDrop ND-1000 Spectrophotometer
(NanoDrop Technologies) and the Agilent 2100 Bioanalyzer (Agilent Technologies). A total of twenty-four intestines were sampled from the parental generation (two to three intestines per tank) and seventy-two livers/intestines were sampled from the offspring generation (four livers/intestines per tank). The sequences of the PCR primers used for the quantification of the mRNA transcriptional levels of the target genes as well as the reference genes are given in Table 2 (Invitrogen, Life Technologies). All primer pairs were tested using a one-step RT PCR kit (Qiagen), and the reaction specificity of each assay was verified by observing a single peak at the expected temperature on the melting curve. The RT reactions were run in triplicate on ninety-six-well reaction plates with the GeneAmp PCR 9700 machine (Applied Biosystems) using TaqMan Reverse Transcription Reagent containing Multiscribe Reverse transcriptase $(50 \mathrm{U} / \mu \mathrm{l})$ (Applied Biosystems). A twofold serial dilution curve (1000-31 ng RNA) of the pooled sample was constructed with six dilutions for the calculation of PCR efficiency. Non-template and non-amplification controls were run in addition to the experimental samples. Total RNA inputs were $250 \mathrm{ng}$ (liver) and $500 \mathrm{ng}$ (intestine) in each RT reaction. Reaction plates with 384 wells were used in which $2 \mu \mathrm{l}$ of complementary DNA from each RT reaction were mixed with $8 \mu$ l of LightCycler 480 SYBR $^{\circledR}$ Green Master Mix (Roche Applied Sciences) with forward and reverse primers ( $500 \mathrm{~nm}$ of each). PCR was achieved with a 5 min activation and denaturation step at $95^{\circ} \mathrm{C}$, followed by forty-five cycles of a $15 \mathrm{~s}$ denaturing step at $95^{\circ} \mathrm{C}$, a $60 \mathrm{~s}$ annealing step and a $30 \mathrm{~s}$ synthesis step at $72^{\circ} \mathrm{C}$. $C_{\mathrm{t}}$ values were calculated using the second maximum derivative method in the Light Cycler $^{\circledR} 480$ software (Roche Applied Sciences). The mean normalised expression of the target genes was determined using a normalisation factor calculated by the geNorm software ${ }^{(23)}$ (Biogazelle). Target genes were 
Table 2. Primer pair sequences and GenBank accession numbers for genes used for quantitative real-time PCR

\begin{tabular}{llll}
\hline Genes & Forward primer & Reverse primer & Accession no. \\
\hline Cyp1A & TCCACTCGATCGCTCCGGGTT & GCGGTTTAGGCGCATGAGCAGAT & NM_131879 \\
CuZn SOD & CCGGCACCGTCTATTTCAAT & GCCGTTTGTGTTGTCACCAA & Y12236 \\
Caspase 6 & AGGACAGCGCTTCAGCAGGACA & TGAGAGCCATTCCCCGTCTCTTGT & NM_001020497 \\
Ghrelin & GTGCCGTGCCAGCAGCATGT & TGGCCTTCGACCCTGCGGTT & NM_001083872 \\
MGAM & TGAGGGGAGAGGCATGCGT & GCTGAGCGCAGGAGGCCATTT & XM_001919100 \\
SIc5a1 & GGACGCACTTGCCCTCCTCA & TCCCACCGCCAGAACCACCA & NM_200681 \\
PCNA & TCGGGTGAGTTTGCCCGCATC & GCCCAGCTCTCCGCTAGCAGA & NM_131404 \\
Cyclin G1 & GACTCCGCGTCATCGAGTCCG & AACGTCTCCGCACAGAAGCCAA & NM_199481 \\
RPL13A & TCTGGAGGACTGTAAGAGGTATGC & AGACGCACAATCTTGAGAGCAG & NM_212784 \\
EF1 $1 \alpha$ & AGACAACCCCAAGGCTCTCA & CTCATGTCACGCACAGCAAA & NM_001017795 \\
\hline
\end{tabular}

Cyp1A, cytochrome P-450, family 1, subfamily A; CUZn SOD, CuZn superoxide dismutase; ghrelin, ghrelin/obestatin prehormone; MGAM, maltase glucoamylase ( $\alpha$-glucosidase); SIc5a1, sodium/glucose co-transporter (family 5, member 1); PCNA, proliferating cell nuclear antigen; $R P L 13 A$, ribosomal protein $L 13 A ; E F 1 \alpha$, elongation factor $1 \alpha$.

normalised against an index of the reference genes (ribosomal protein L13A (Rpl13a) and elongation factor $1(E F 1 \alpha))$. The reference genes were stable with gene expression stability (M) values of 0.41 (liver), 0.68 (mid-intestine, F0) and 0.19 (mid-intestine, F1).

\section{Differential leucocyte counts (parental generation)}

Within $24 \mathrm{~h}$ of sampling, all blood films were stained with the May-Grünwald stain (Merck \& Company, Inc.) for 5 min and the Giemsa stain (Merck \& Company, Inc.) for $15 \mathrm{~min}$. From each fish sampled, 100 leucocytes were counted and identified either as lymphocytes, granulocytes or monocytes and expressed as a percentage of the total number of leucocytes examined. Each sample was blinded and examined randomly with an Olympus light microscope (BX 51) (Olympus).

\section{Copper zinc superoxide dismutase enzyme activity (parental generation)}

Individual liver samples from the parental generation were prepared by adding $500 \mu \mathrm{l}$ of a cold buffer (20 mM-HEPES, $\mathrm{pH} 7 \cdot 2$, containing $1 \mathrm{~mm}$-ethylene glycol tetraacetic acid (EGTA), $210 \mathrm{~mm}$-mannitol and $70 \mathrm{~mm}$-sucrose) before being homogenised at $3 \times 10 \mathrm{~s}$ at $6000 \mathrm{rpm}$ (Precellys 24 homogeniser; Bertin Corp.). The samples were then centrifuged at $10000 \mathrm{~g}$ for $15 \mathrm{~min}$ at $4^{\circ} \mathrm{C}$ before the supernatant was collected and stored at $-80^{\circ} \mathrm{C}$ for later enzyme analysis. CuZn SOD enzyme activity was assayed according to the assay protocol (SOD assay kit, item no. 706002, Cayman Chemical Company). The absorbance was read at $450 \mathrm{~nm}$ using a standard plate reader with a shaker. Using a standard protein assay kit (Pierce ${ }^{\circledR}$ BCA protein assay kit, Thermo Scientific, Pierce Biotechnology), one-third of the supernatant was used for assaying the protein content. The definition of one unit of SOD activity (U) is as follows: the quantity of enzyme required to cause $50 \%$ dismutation of the superoxide radical. The results are expressed as $\mathrm{U} / \mathrm{min}$ per $\mathrm{mg}$ protein.

\section{Fecundity measurements (parental generation)}

For the reproductive study, 5-litre breeding tanks equipped with a spawning tray, which consisted of a fine net with an appropriate mesh size for eggs to fall through, close to the bottom of the tank, were used. Males and females from each dietary group were housed separately until the next morning when the light period commenced and they were allowed to breed. The measure of reproductive success was the number of eggs produced by the females per dietary group. Subsequently, after each fecundity experiment, eggs were collected and counted from each group $3 \mathrm{~h}$ after the beginning of the light period. Fecundity data are based on groups of females $^{(2-4)}$ mating with three males and are cumulative values that also include the impact of unfertilised eggs.

\section{Analysis of global DNA methylation (offspring generation)}

Eggs were carefully rinsed in system water before being incubated with the $\mathrm{E} 3$ medium $(5 \mathrm{~mm}-\mathrm{NaCl}, 0 \cdot 17 \mathrm{~mm}-\mathrm{KCl}$,

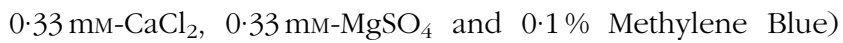
at $29^{\circ} \mathrm{C}$, collected at $51 \mathrm{~h}$ post-fertilisation and preserved in liquid $\mathrm{N}_{2}$ for later DNA methylation analysis. The total numbers of embryos analysed from each group were 240 (Bt-maize group) and 330 ( $n B t$-maize group). DNA from the embryos was prepared using the method of Skjærven et $a l^{(24)}$ as modified by Ramsahoye ${ }^{(25)}$. Briefly, thirty pooled embryos were thoroughly homogenised in $1 \mathrm{ml}$ of TRIzol (Invitrogen, Life Technologies) using a pestle before homogenising at $3 \times 10 \mathrm{~s}$ at $6000 \mathrm{rpm}$ (Precellys 24 homogeniser; Bertin Corp.). Total DNA was extracted according to the TRIzol protocol before being further purified and digested into nucleotides ${ }^{(24)}$. The samples were stored at $-80^{\circ} \mathrm{C}$ until further HPLC analyses. Isocratic reverse-phase HPLC was used to analyse the $\mathrm{DNA}^{(24)}$. Briefly, the mobile phase (20 mm-orthophosphoric acid, $\mathrm{pH} 2.5$ ) was filtered before use and was run through the HPLC system for approximately $15 \mathrm{~min}$ at $0.5 \mathrm{ml} / \mathrm{min}$ and $30 \mathrm{~min}$ at $1.0 \mathrm{ml} / \mathrm{min}$ before each sample series to stabilise the system. The flow of the mobile phase was set to $1 \mathrm{ml} / \mathrm{min}$ during the analysis. After each sample series, the HPLC system was washed with 5\% acetonitrile in water for at least $2 \mathrm{~h}$. The samples were run together with nucleotide standards combined in a standard mix. The standard mix consisted of cytosine (dCMP; 2'-deoxycytidine 5'-monophosphate; Sigma D7750), uracil (2,4-dihydroxypyrimidine, Sigma U0750) and methylated cytosine (5mdCMP; 5-methyl deoxycytidine 5'-monophosphate, 
disodium salt, Reliable Biopharmaceutical product no. 61-1979). Uracil was included in the standard mix as a reference for RNA-free DNA. The percentage of 5-methylcytosine nucleotides was calculated using the following formula ${ }^{(25)}$ :

$$
\operatorname{mdCMP}(\text { as } \% \text { of total } \mathrm{C})=\frac{\mathrm{nmol} \text { of } \mathrm{mdCMP}}{\mathrm{nmol}(\mathrm{mdCMP}+\mathrm{dCMP})} \times 100 \text {. }
$$

The molar equivalent of each nucleotide was calculated using the areas under each peak divided by the extinction coefficients for the nucleotides (extinction coefficient for dCMP $=9300$ and $\mathrm{mdCMP}=8600)$.

\section{Analysis of the swimming activity of larvae (offspring generation)}

At $4 \mathrm{dph}$, the F1 larvae were placed individually in wells of a ninety-six-well plate containing the $\mathrm{E} 3$ medium, and swimming activity was measured using the ZebraLab Quantization software (Viewpoint Life Sciences) equipped with an IR light source, a high-resolution digital IR camera and a hood to exclude external light. Swimming activity was measured for $60 \mathrm{~min}$ with alternating light and dark cycles of $10 \mathrm{~min}$. Movement was captured within predefined areas (freezing area, low-movement activity; mid-area, medium-movement activity; burst area, high-movement activity), and output parameters were duration and counts within each area. The sum of total duration was always $60 \mathrm{~min}$. Each time the larvae moved from one area to another, one count was registered, and the counts varied from 100 in slow larvae to 10000 in active larvae. The total numbers of larvae analysed for each group were 131 (Bt-maize group) and 281 ( $n B t$-maize group).

\section{Histological evaluation of zebrafish intestines (offspring generation)}

From the paraffin-embedded intestinal tissues, longitudinal and/ or transverse sections $(3 \mu \mathrm{m})$ were cut and stained with haematoxylin and eosin and mounted on glass microscope slides. Intestinal tissues (proximal intestine and mid-intestine) of all the sections were blinded and evaluated by trained personnel using a light microscope (Carl Zeiss, Inc.), and images were captured using the AxioVision Rel. 4.7 software (Kemet International Limited). Morphology was evaluated according to the following criteria: (1) enterocyte nucleus position; (2) enterocyte vacuolisation; (3) submucosal width and cellularity; (4) lamina propria width and cellularity; (5) intraepithelial leucocyte frequency; (6) enterocyte hyperplasia; (7) goblet cell frequency; (8) presence of mucosal fold fusion. Serial sections were evaluated when necessary. The degree of histological changes was assessed as normal, mild, moderate or severe.

\section{Calculations}

$$
\begin{aligned}
& \mathrm{CF}=\left(\frac{\text { body weight }(\mathrm{mg})}{\text { fork length }(\mathrm{mm})^{3}}\right) \times 100, \\
& \mathrm{FCR}=\frac{\text { feed eaten }(\mathrm{mg})}{\text { body mass increase }(\mathrm{mg})},
\end{aligned}
$$

Specific growth rate

$$
=\left(\frac{\ln \text { final weight }-\ln \text { initial weight }}{\text { duration of study in days }}\right) \times 100 .
$$

\section{Statistical analysis}

Statistical analysis was conducted using Statistica ${ }^{\text {TM }} 7$ (StatSoft, Inc.) and GraphPad Prism 5 (GraphPad Software, Inc.). A oneway ANOVA (general lineal model) or unpaired $t$ test was used for data obtained from the F1 or F0 generation, respectively. Data were always evaluated to ensure that the criteria for performing the statistical tests were fulfilled (Bartlett's test for equal variances). In cases when the ANOVA showed significant differences, post hoc tests (Tukey's honestly significant difference test or Fisher's least significant difference test) were used to find which groups differed. Data from the histological evaluations were subjected to a contingency analysis. Data obtained from the pooled fish tanks, performance parameters (F0) after $283 \mathrm{~d}$ (Bt-maize: $n$ 11; $n B t$-maize: $n$ 10), CuZn SOD enzyme analysis (Bt-maize: $n 11 ; n B t$-maize: $n$ 10), leucocyte counts (Bt-maize: $n$ 6; $n B t$-maize: $n$ 8) and reproduction parameters, are reported as means with their $95 \%$ CI. All reported $P$ values are two sided and significance was set at $P<0.05$.

\section{Results}

Diets, performance parameters and gene transcripts parental generation

The diets were considered nutritionally equivalent except for the presence of the transgenic Cry1Ab protein and elevated levels of mycotoxin DON in the $B t$-maize diet and mycotoxins FB1 and AFLB1 in the nBt-maize diet (Table 1). Of more than 300 pesticides analysed, only trace levels of diphenylamine $(0.03-0.05 \mathrm{mg} / \mathrm{kg})$ were detected in the two maize diets. Fish in all tanks were fed identical amounts of feed every day according to body mass, and all feed was consumed immediately, indicating good feed acceptance. Mortality was recorded on a daily basis with no mortality recorded until the end of the trial in which two fish died from each of the dietary groups. A total of $159 \mathrm{mg}$ of feed was given to the fish per tank during the first $45 \mathrm{~d}$ of the feeding trial. Performance was not affected by the experimental feeds as assessed by body mass increase, fish length, condition factor (CF) and feed conversion ratio (FCR, Tables 3 and 4). After $45 \mathrm{~d}$, body mass ranged from 169 to $188 \mathrm{mg}$ with no significant differences $(P=0 \cdot 30)$ being observed between the two feeding groups, and after $283 \mathrm{~d}$, body mass ranged from 481 to $491 \mathrm{mg}$ (Table 4). The CF was 1.0 for both the feeding groups after $45 \mathrm{~d}$, and after $283 \mathrm{~d}$, the CF were $1 \cdot 1(95 \%$ CI $1 \cdot 0,1 \cdot 1)$ for the $n B t$-maize diet-fed fish and 1.3 (95\% CI $0.9,1.7)$ for the $B t$-maize diet-fed fish. FCR, which is the ratio of the amounts of feed consumed to fish weight gain, ranged from 0.8 to 0.9 ( $45 \mathrm{~d}$ ), indicating good feed utilisation. Liver oxidative status was assessed after $283 \mathrm{~d}$ of feeding by investigating CuZn SOD enzyme activity in the parental zebrafish. The specific 
Table 3. Growth performance parameters and mean normalised expression (MNE) of genes in the mid-intestine of the parental zebrafish (F0) fed the $n B t$ (non-Bacillus thuringiensis)-maize and Bt-maize diets for $45 \mathrm{~d}$

(Means with their standard errors (growth data: ten fish per tank; gene transcript data: two to three fish per tank; $n 3$ per diet))

\begin{tabular}{|c|c|c|c|c|c|}
\hline & \multicolumn{2}{|c|}{$n B t$-maize } & \multicolumn{2}{|c|}{ Bt-maize } & \multirow[b]{2}{*}{$P^{*}$} \\
\hline & Mean & SEM & Mean & SEM & \\
\hline \multicolumn{6}{|c|}{ Growth performance $45 \mathrm{~d}(\mathrm{~F} 0) \dagger$} \\
\hline BM increase $\neq(\mathrm{mg})$ & $169 \cdot 3$ & $15 \cdot 7$ & $188 \cdot 3$ & 3.4 & 0.30 \\
\hline Final length $(\mathrm{mm})$ & $26 \cdot 1$ & 0.6 & $26 \cdot 9$ & $0 \cdot 2$ & 0.27 \\
\hline $\mathrm{CF}$ & 1.0 & 0.0 & 1.0 & 0.0 & 0.65 \\
\hline FCR $\ddagger$ & 0.9 & $0 \cdot 1$ & $0 \cdot 8$ & 0.0 & 0.31 \\
\hline \multicolumn{6}{|c|}{ Mid-intestine MNE $45 \mathrm{~d}$ (F0) } \\
\hline MGAM & 0.49 & 0.08 & 0.45 & 0.09 & 0.78 \\
\hline S/c5a1 & 0.84 & 0.09 & 0.80 & 0.07 & 0.71 \\
\hline CuZn SOD & $1 \cdot 13$ & 0.07 & 1.25 & 0.06 & 0.23 \\
\hline Сур1А & 0.71 & 0.03 & 0.87 & $0 \cdot 10$ & 0.19 \\
\hline Caspase 6 & 0.92 & 0.03 & 0.99 & 0.06 & 0.76 \\
\hline Ghrelin & 0.59 & 0.09 & 0.88 & $0 \cdot 15$ & 0.17 \\
\hline
\end{tabular}

$\mathrm{BM}$, body mass; CF, condition factor; FCR, feed conversion ratio; MGAM, maltase glucoamylase; S/c5a1, sodium glucose co-transporter; CUZn SOD, CuZn superoxide dismutase; Cyp1A, cytochrome P-450 1A; ghrelin, ghrelin prehormone.

* Differences between the treatment groups were tested using an unpaired, two-tailed $t$ test $(P<0.05)$.

$\dagger$ Initial body weight 13 (SD 6) mg and length 12 (SD 2) $\mathrm{mm}$.

†Feed intake per fish was calculated based on the total amount of feed given per tank, which was $159 \mathrm{mg} / \mathrm{fish}$. All feed was weighed before feeding.

enzyme activity ranged from $8 \cdot 2(95 \%$ CI $6 \cdot 1,10 \cdot 2)$ to $8 \cdot 3(95 \%$ CI $6 \cdot 3,10 \cdot 3) \mathrm{U} / \mathrm{min}$ per $\mathrm{mg}$ protein with no differences being observed between the groups (Table 4). After $45 \mathrm{~d}$ of feeding, blood samples were collected from the adult fish (F0), and lymphocytes, monocytes and granulocytes were counted (Table 4). The lymphocyte mean population ranged from 81 to $89 \%$, the monocyte population from 9 to $13 \%$ and the granulocyte population from 3 to $5 \%$. The mean normalised expression of maltase glucoamylase $(M G A M)$, sodium glucose co-transporter (Slc5a1), CuZn SOD, cytochrome P-450 1A (Cyp1A), caspase 6 and ghrelin in the mid-intestine is reported in Table 3. There were no significant differences between the feeding groups for any of the selected transcripts.

\section{Reproduction parameters}

Fish fed the $n B t$-maize diet had the highest mean fecundity with 203 (95\% CI 117, 290) eggs per female, followed by fish fed the $B t$-maize diet, which exhibited 16\% lower mean fecundity (Table 5). The percentage of 5-methylcytosine nucleotides in embryos ( $51 \mathrm{~h}$ post-fertilisation) did not differ between the groups (Table 5). The embryos at this developmental stage had between $7 \cdot 2(95 \%$ CI $7 \cdot 1,7 \cdot 3)$ and $7 \cdot 4$ (95\% CI 6.0, 8.9) \% of 5-methylcytosine nucleotides. Swimming activity measurements of the F1 larvae at $4 \mathrm{dpf}$ showed that fish from both the feeding groups spent the same amount of time in the high-activity zone, burst zone (burst duration) (Table 5).

Table 4. Differential counts of leucocytes (granulocytes, monocytes and lymphocytes) and growth performance parameters including liver CuZn superoxide dismutase (SOD) activity of parental zebrafish fed the $n B t$ (non-Bacillus thuringiensis)-maize and Bt-maize diets for $45 \mathrm{~d}$ (F0, parental generation) and $283 \mathrm{~d}$ (F0 generation), respectively

(Mean values and $95 \%$ confidence intervals (blood health data: six to eight fish per diet; growth data: ten to eleven fish per diet))

\begin{tabular}{|c|c|c|c|c|}
\hline & \multicolumn{2}{|c|}{$n B t$-maize } & \multicolumn{2}{|c|}{ Bt-maize } \\
\hline & Mean & $95 \% \mathrm{Cl}$ & Mean & $95 \% \mathrm{Cl}$ \\
\hline \multicolumn{5}{|l|}{ Blood health $45 \mathrm{~d}(\mathrm{~F} 0)$} \\
\hline Lymphocytes & 81 & 68,94 & 89 & 84,94 \\
\hline Monocytes & 13 & 5,22 & 9 & 6,13 \\
\hline Granulocytes & 5 & 1,8 & 3 & 1,4 \\
\hline \multicolumn{5}{|l|}{ Growth performance $283 \mathrm{~d}(\mathrm{~F} 0)^{\star}$} \\
\hline BM increase (mg) & 482 & 432,531 & 491 & 451,531 \\
\hline Final length (mm) & 36 & 35,37 & 34 & 32,37 \\
\hline $\mathrm{CF}$ & $1 \cdot 1$ & $1 \cdot 0,1 \cdot 1$ & 1.3 & $0.9,1.7$ \\
\hline Liver CuZn SOD (U/min per mg protein) & $8 \cdot 2$ & $6 \cdot 1,10 \cdot 2$ & $8 \cdot 3$ & $6 \cdot 3,10 \cdot 3$ \\
\hline
\end{tabular}

$\mathrm{BM}$, body mass; $\mathrm{CF}$, condition factor.

*Only males. 
Table 5. Reproductive parameters of the parental generation (Fo) fed the two experimental diets ( $n B t$ (non-Bacillus thuringiensis)-maize or Bt-maize) as assessed by fecundity, embryo DNA methylation (F1) given as percentage occurrence of 5-methylcytosine in offspring zebrafish embryos (51 h post-fertilisation) and larva swimming activity (F1) given as a percentage of burst duration

(Mean values and $95 \%$ confidence intervals)

\begin{tabular}{|c|c|c|c|c|}
\hline & \multicolumn{2}{|c|}{$n B t$-maize } & \multicolumn{2}{|c|}{ Bt-maize } \\
\hline & Mean & $95 \% \mathrm{Cl}$ & Mean & $95 \% \mathrm{Cl}$ \\
\hline \multicolumn{5}{|l|}{ Reproductive parameters } \\
\hline Fecundity (FO)* & 203 & 117,290 & 170 & 78,262 \\
\hline 5-Methylcytosine percentage $(\mathrm{F} 1) \dagger$ & 7.4 & $6 \cdot 0,8.9$ & $7 \cdot 2$ & $7 \cdot 1,7 \cdot 3$ \\
\hline Burst duration percentage $(\mathrm{F} 1) \ddagger$ & 0.5 & $0.1,0.8$ & 0.5 & $-0.7,1 \cdot 7$ \\
\hline
\end{tabular}

\section{Performance parameters and gene transcripts - offspring generation}

Fish in all tanks were fed the same amounts of feed every day according to satiety (F1), and all feed was consumed immediately, indicating good feed acceptance. While the parental zebrafish were subjected to a restricted feeding regimen (e.g. fed according to body mass), the offspring zebrafish were fed according to a pair-feeding regimen (e.g. according to satiety) and were fed approximately $44 \%$ more than their parents. The difference in feeding regimens was clearly reflected in the performance parameters, resulting in a higher body mass increase and a higher CF compared with those in fish from the parental generation (F0) (Tables 3 and 6). Fish from the parental generation exhibited better feed utilisation than those from the offspring generation, resulting in a higher FCR for the offspring fish (Tables 3 and 6). The $B t$-maize diet-fed offspring from the $B t$-maize diet-fed parents $(B t-B t)$ exhibited a significantly higher body mass increase $(P=0.0003)$ and specific growth rate $(P=0.0005)$ than the $n B t$-maize diet-fed offspring from the $n B t$-maize diet-fed parents $(n B t-n B t)$ and offspring from

Table 6. Growth performance parameters and mean normalised expression (MNE) of gene transcripts in the mid-intestine and liver of offspring zebrafish $(\mathrm{F} 1)$ fed the three dietary regimens for $45 \mathrm{~d}$ : Bt (Bacillus thuringiensis)maize diet-fed offspring from the $B t$-maize diet-fed parents $(B t-B t, n 4)$, non-Bt ( $n B t)$-maize diet-fed offspring from the $B t$-maize diet-fed parents $(B t-n B t, n 3)$ and $n B t$-maize diet-fed offspring from the $n B t$-maize diet-fed parents $(n B t-n B t, n 5)$

(Mean values with their standard errors (growth data: fourteen fish per tank; gene transcript data: six fish per tank))

\begin{tabular}{|c|c|c|c|c|c|c|c|}
\hline & \multicolumn{2}{|c|}{$B t-B t$} & \multicolumn{2}{|c|}{$B t-n B t$} & \multicolumn{2}{|c|}{$n B t-n B t$} & \multirow[b]{2}{*}{$P$} \\
\hline & Mean & SEM & Mean & SEM & Mean & SEM & \\
\hline \multicolumn{8}{|c|}{ Growth performance $45 \mathrm{~d}(\mathrm{~F} 1)^{*}$} \\
\hline $\mathrm{BM}$ increase (mg) & $257 \cdot 8^{a}$ & $4 \cdot 5$ & $215 \cdot 3^{b}$ & $4 \cdot 4$ & $221 \cdot 2^{b}$ & $4 \cdot 8$ & 0.0003 \\
\hline Final length (mm) & $26 \cdot 5$ & 0.3 & $25 \cdot 2$ & $1 \cdot 1$ & $25 \cdot 6$ & 0.3 & 0.28 \\
\hline $\mathrm{CF}$ & 1.5 & $0 \cdot 0$ & 1.4 & $0 \cdot 1$ & 1.5 & 0.0 & 0.44 \\
\hline FCR & $1 \cdot 1^{\mathrm{b}}$ & 0.0 & $1 \cdot 4^{\mathrm{a}}$ & 0.1 & $1 \cdot 3^{a, b}$ & 0.0 & 0.02 \\
\hline FI per fish (mg) & $285 \cdot 2$ & $15 \cdot 2$ & $296 \cdot 4$ & $12 \cdot 7$ & $277 \cdot 6$ & $11 \cdot 2$ & 0.63 \\
\hline SGR & $6 \cdot 1^{a}$ & 0.0 & $5 \cdot 7^{\mathrm{b}}$ & 0.0 & $5 \cdot 8^{\mathrm{b}}$ & 0.1 & 0.0005 \\
\hline \multicolumn{8}{|c|}{ Mid-intestine MNE $45 \mathrm{~d}(\mathrm{~F} 1)$} \\
\hline MGAM & 0.53 & 0.10 & 0.41 & 0.05 & 0.57 & 0.09 & 0.32 \\
\hline Slc5a1 & 0.66 & 0.13 & 0.51 & 0.09 & 0.62 & 0.05 & 0.48 \\
\hline CUZn SOD & $0.76^{b}$ & 0.03 & $0.89^{a, b}$ & 0.09 & $1.03^{a}$ & 0.05 & 0.03 \\
\hline Cур1A & 0.37 & 0.03 & 0.60 & 0.23 & 0.53 & 0.09 & 0.42 \\
\hline Caspase 6 & $1 \cdot 13$ & 0.13 & 0.94 & 0.06 & 0.95 & 0.03 & 0.25 \\
\hline Ghrelin & 0.17 & 0.05 & 0.28 & 0.03 & 0.28 & 0.06 & 0.31 \\
\hline PCNA & $0 \cdot 30$ & 0.05 & 0.17 & 0.06 & 0.26 & 0.08 & 0.45 \\
\hline \multicolumn{8}{|l|}{ Liver MNE $45 \mathrm{~d}(\mathrm{~F} 1)$} \\
\hline Cyclin G1 & 0.75 & 0.06 & 0.78 & 0.02 & 0.84 & 0.04 & 0.34 \\
\hline Caspase 6 & $0.73^{a}$ & 0.09 & $0.52^{a, b}$ & 0.09 & $0.38^{b}$ & 0.02 & 0.01 \\
\hline CuZn SOD & $0.59^{b}$ & 0.10 & $0.65^{a, b}$ & 0.05 & $0.91^{a}$ & 0.05 & 0.02 \\
\hline Сур1А & 0.40 & 0.07 & 0.52 & 0.19 & 0.59 & 0.11 & 0.53 \\
\hline
\end{tabular}

$\mathrm{BM}$, body mass; CF, condition factor; FCR, feed conversion ratio, FI, feed intake; SGR, specific growth rate; $M G A M$, maltase glucoamylase; SIc5a1, sodium glucose co-transporter; CuZn SOD, CuZn superoxide dismutase; Cyp1A, cytochrome P-450 1A; ghrelin, ghrelin prehormone, PCNA, proliferating cell nuclear antigen.

a,b Mean values within a row with unlike superscript letters were significantly different $(P<0.05$; one-way ANOVA).

* Initial body weight 21 (SD 8) $\mathrm{mg}$ and length 11 (SD 2) $\mathrm{mm}$. 
the cross-over dietary regimen $(B t-n B t)$ (Table 6). Feed utilisation was different between the feeding groups with a significantly higher FCR $(P=0.02)$ in offspring fed the crossover regimen $(B t-n B t)$ than in the $B t-B t$ offspring. The final fish length was independent of the dietary feeding regimens and was between 25 and $27 \mathrm{~mm}$. The $B t-B t$ offspring exhibited a significantly higher level of liver caspase $6(P=0 \cdot 01)$ and a lower level of liver and mid-intestine CuZn SOD (liver $P=0.02$ and mid-intestine $P=0 \cdot 04$ ) than the $n B t-n B t$ offspring (Table 6). There were no significant differences between the feeding groups for any of the other gene transcripts in the mid-intestine.

\section{Histological evaluation of the intestine (offspring generation)}

In general, the intestinal epithelium consists of a single layer of column-shaped enterocytes with basally positioned nuclei and mucus-secreting goblet cells. Enteroendocrine-like cells are mainly scattered at the base of the mucosal folds. The lamina propria and submucosa are very thin with few cells present. The mucosal layer is directly ensheathed by inner circular and outer longitudinal smooth muscle cells of the muscularis layer. According to the morphological characteristics, the intestine can be divided into two regions: proximal intestine and mid-intestine. The proximal intestine displays extensive epithelial folding, while the mid-intestine is distinguished by the presence of large supranuclear vacuoles in the enterocytes. Most proximal intestinal samples displayed normal epithelial morphology. Mild changes were exhibited by five samples. No effects of diets, however, were detected (Table 7; Fig. 2(a) and (b)). Among the five samples from the proximal intestine, two samples $(n B t-n B t$ and $B t-B t)$ exhibited mild enterocyte hyperplasia accompanied by increased goblet cell frequency. The presence of intraepithelial leucocytes was slightly increased. The $n B t-n B t$ sample also displayed a mild degree of mucosal fold fusion, and the $B t-B t$ sample exhibited widened lamina propria accompanied by connective tissue hyperplasia. The other three proximate intestinal samples (two $n B t-n B t$ samples and one $B t-n B t$ sample) mainly displayed mild increases in intraepithelial

Table 7. Morphological evaluation of the intestines sampled from the offspring generation (F1): $n B t$ (non-Bacillus thuringiensis)-maize diet-fed offspring from the $n B t$-maize diet-fed parents ( $n B t-n B t$, ten fish), $n B t$-maize diet-fed offspring from the Bt-maize diet-fed parents $(B t-n B t$, eight fish) and $B t$-maize diet-fed offspring from the $B t$-maize diet-fed parents $\left(B t-B t\right.$, six fish) ${ }^{\star}$

\begin{tabular}{lcccc}
\hline & $B t-B t$ & $B t-n B t$ & $n B t-n B t$ & $P \dagger$ \\
\hline Proximal intestine & & & & 0.7541 \\
$\quad$ Normal structure & 6 & 3 & 7 & \\
$\quad$ Mild changes & 1 & 1 & 3 & 0.2966 \\
Mid-intestine & & & & \\
$\quad$ Normal structure & 3 & 5 & 4 & \\
$\quad$ Mild changes & 4 & 1 & 4 & \\
\hline
\end{tabular}

${ }^{*}$ Values signify the number of zebrafish per dietary treatment that displayed the various degrees of morphological changes in the proximal intestine and mid-intestine.

†Differences between the treatment groups were tested using a contingency analysis, and $P$ values are given.

$\ddagger$ Some segments of the intestine were damaged during the processing and explain the different number for the two intestinal segments.
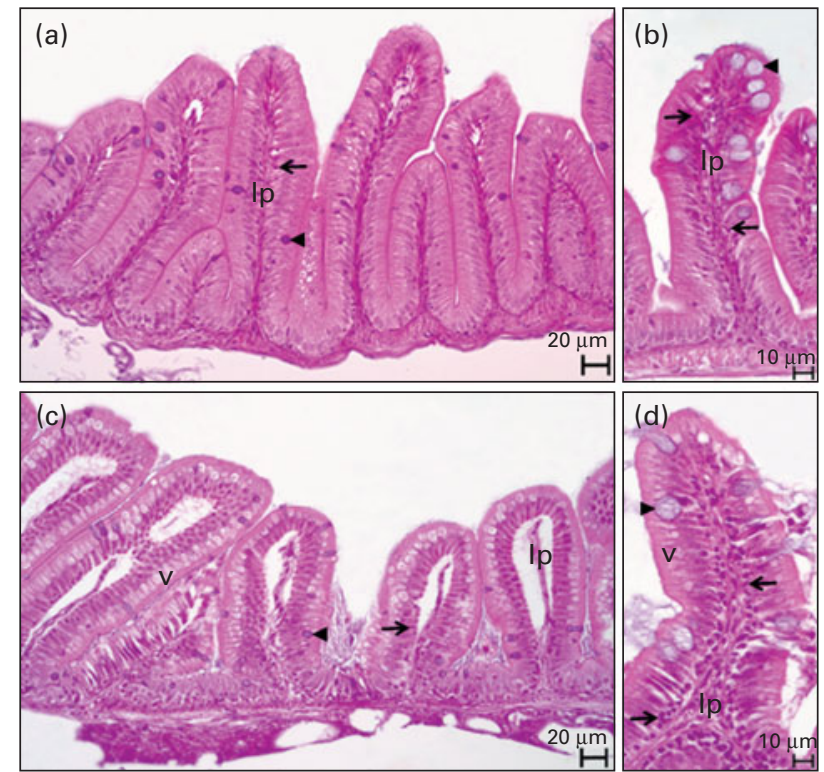

Fig. 2 Histological details of the (a, b) proximal and (c, d) mid-intestinal regions of the offspring zebrafish (F1) fed the three dietary regimens for $45 \mathrm{~d}$ : $B t$ (Bacillus thuringiensis)-maize diet-fed offspring from the Bt-maize diet-fed parents $(B t-B t)$; non- $B t(n B t)$-maize diet-fed offspring from the $B t$-maize dietfed parents $(B t-n B t) ; n B t$-maize diet-fed offspring from the $n B t$-maize diet-fed parents $(n B t-n B t)$. Compared with the normal morphological structure of proximal intestine (a), a few of the fish (see Table 6) exhibited slight changes (b) with widened lamina propria (Ip) and increased frequencies of intraepithelial leucocytes $(\rightarrow)$ and goblet cells $(\triangleleft)$. Compared with the normal morphological structure of the mid-intestine (c), one fish exhibited mild inflammatory changes (d), indicated by the increased presence of intraepithelial leucocytes $(\rightarrow$ ) accompanied by widened Ip, increased number of goblet cells and decreased supranuclear vacuolisation ( $v$ ) in enterocytes. A few fish only exhibited decreased supranuclear vacuolisation in enterocytes. (A colour version of this figure can be found online at http://www.journals.cambridge.org/bjn)

leucocyte frequency with or without widened lamina propria. Taking the enterocyte supranuclear vacuolisation into account, nine of twenty-one mid-intestinal samples exhibited mild morphological alterations. No effects of diets were detected (Table 7; Fig. 2(c) and (d)). Mild inflammatory changes were exhibited by one $B t-B t$ mid-intestinal sample, indicated by the increased presence of intraepithelial leucocytes accompanied by widened lamina propria and increased number of goblet cells and decreased supranuclear vacuolisation in enterocytes. The other eight samples with mild changes only exhibited mild-to-moderate decreases in enterocyte supranuclear vacuolisation. No changes were observed in the distal intestine (data not shown).

\section{Discussion}

To our knowledge, this is the first report on a crossgenerational $B t$-maize feeding trial in a teleost fish. Based on the parameters investigated, no long-term adverse effects of $B t$-maize in either the F0 generation or the F1 generation were observed, indicating that a 19\% inclusion level was either non-toxic or did not result in responses detectable with the analytical methods used or visible with a light microscope. Because zebrafish have a short generation time and are relatively easy to breed, this model was selected to potentially 
reveal specific target endpoints that could be used to assess the long-term effects of $B t$-maize ingredients in aquaculture feeds. The present feed production technique using only low temperatures $\left(40^{\circ} \mathrm{C}\right)$ was also more likely to prevent possible heat inactivation of the Cry1 $\mathrm{Ab}$ protein compared with commercial extruded fish feeds ${ }^{(11,26)}$. Although the exact Cry1Ab protein level in Bt-maize (MON810) is dependent on the growth stage of the plant and the plant tissue, an average content of Cry $1 \mathrm{Ab}$ of $300 \mathrm{ng} / \mathrm{g}$ wet weight of harvested grains has been reported ${ }^{(27)}$. However, any Cry1Ab present locally in the intestine of zebrafish did not appear to negatively influence growth, intestinal functional gene expression or histomorphology. Nor did any possible absorbed Cry1Ab appear to adversely affect systemic parameters: (1) leucocyte counts indicated predominantly lymphocytes, with an overall mean proportion of $84 \%$, which is slightly higher than the mean values reported by Murtha et $a l^{(28)}$, but well within the normal range reported for zebrafish lymphocytes, which is between 71 and $92 \%^{(28)}$; (2) levels of gene transcripts involved in DNA repair, detoxification, oxidative stress and apoptosis in the liver were apparently not adversely affected; (3) reproductive parameters were not affected.

Interestingly, offspring zebrafish fed the $B t$-maize diet exhibited enhanced growth performance than those fed the $n B t$-maize diet, as indicated by higher specific growth rate and body mass increase. Although no significant differences were observed in the parental generation (F0), the same trends were observed. The difference between the generations may be explained by the use of ad libitum feeding regimen in the offspring fish (F1) as opposed to a restricted feeding regimen for the F0 generation. Despite not being significant in the parental generation (F0), the numerical difference was in the same direction for the F0 generation. The $B t-B t$ offspring had significantly decreased expression levels of CuZn SOD in both the liver and mid-intestine, which may indicate reduced oxidative stress in these tissues, than the $n B t-n B t$ offspring. Offspring fish fed the $B t$-maize diet also exhibited higher gene transcript levels of hepatic caspase 6 , which may indicate that pathways in the cell cycle were affected by dietary factors. However, for the other gene biomarkers, no significant differences were observed. Nor were dietrelated histomorphological changes in the intestine observed. Another study, which focused on the long-term effects in $B t$-maize-fed pigs, found no local or systemic allergic or inflammation-type immune responses ${ }^{(29)}$. Enhanced growth performance in zebrafish fed $B t$-maize than in those fed $n B t$-maize has also been observed in a previous trial ${ }^{(7)}$ where ad libitum feeding was used.

Increased growth with Bt-maize feeding than with $n B t$-maize one has also been reported for other animal species and has been hypothesised to be due to reduced DON content in $B t$-maize ${ }^{(30)}$. Clearly, this was not supported in the present study since DON levels in the $B t$-maize diet were higher than those in the $n B t$-maize diet (Table 1). Furthermore, lack of DON effects on growth performance has recently been reported in another zebrafish trial, in which concentrations of DON much higher than those used in the present study were used $^{(14)}$. In the previous zebrafish study ${ }^{(7)}$, reduced mycotoxin levels in Bt-maize were also speculated to be the cause of the enhanced growth. However, retrospective analysis of the maize used in that study revealed that $B t$-maize in fact had a higher DON content than $n B t$-maize ${ }^{(13)}$. Consequently, those results are similar to the ones presented here, making it less likely that these are random findings, although the cause is not clear.

On the other hand, the nBt-maize diet contained low, but detectable levels of AFLB1 and FB1 than the Bt-maize diet. Thus, it cannot be ruled out that these mycotoxins may have contributed to the reduced growth and other responses in the $n B t$-maize diet-fed fish. For fumonisins, a non-observable effect level for feed was set to $3 \mathrm{mg} / \mathrm{kg}$ for rainbow trout ${ }^{(31)}$, and for AFLB1, it has been reported that $0 \cdot 4 \mu \mathrm{g} / \mathrm{kg}$ feed can cause haematomas when fed to rainbow trout for 15 months ${ }^{(32)}$. In the $n B t$-maize diet used in the present study, the level of AFLB1 was $0 \cdot 4 \mu \mathrm{g} / \mathrm{kg}$ and the level of FB1 was $23 \mu \mathrm{g} / \mathrm{kg}$. Although the individual levels of AFLB1 and FBI were low in our diets, synergism has been reported for these two mycotoxins with decreased body weight gain as the most frequently reported effect ${ }^{(33)}$. Fumonisins are inhibitors of ceramide synthase, a key enzyme in lipid metabolism, and as a consequence the levels of free sphingoid bases may be elevated. Free sphingoid bases have been found to be toxic to most cells by affecting cell proliferation and inducing apoptosis or necrotic cell death ${ }^{(34)}$. Aflatoxins, on the other hand, may act as carcinogens by forming DNA adducts and could affect apoptosis and cell proliferation by causing mutations in these genes ${ }^{(35)}$. In the present study, a decreased liver gene transcript level of caspase 6 (execution phase of apoptosis) was observed concomitant with an increased liver and mid-intestinal gene transcript level of CuZn SOD in the $n B t-n B t$ offspring. Higher liver gene transcript levels of Cyp1A in these fish were also observed, but they were not significant due to large variations between the tanks within the same dietary group. Thus, the decreased growth in the $n B t$-maize groups may indicate changed energy metabolism due to, for example, energy-demanding processes such as cellular detoxification, increased cellular proliferation/apoptosis and/or oxidative stress. Further control groups could have made it easier to understand and explain the unexpected differences observed between the two groups, but such groups were not possible to obtain in the present study. Overall, however, the growth performance in the present study was comparable to that reported in other studies using noncommercial diet formulations ${ }^{(7,14,36)}$. Compared with the growth performance of zebrafish fed commercial diets and live feed, the growth observed in the present study was lower in both the feeding groups ${ }^{(37)}$.

Other targets in the present study were the reproductive performance of the parental generation (fecundity), offspring larva swimming behaviour and DNA methylation in embryos. Reproductive performance has also been investigated in mice fed $B t$-maize with a focus on testicular development. Ingestion of $B t$-maize by mothers during pregnancy and later by the young developing male mice had no negative effects on fetal, postnatal, pubertal or adult testicular development or body growth ${ }^{(38)}$. The overall mean number of eggs produced 
by the zebrafish was 189 , which corresponds to what has been reported in the literature. The present study found no differences between the feeding groups. In the present study, DNA isolated from embryos obtained from the exposed parental generation was analysed using HPLC to determine the relative amount of cytosine and 5-methylcytosine nucleotides. Methylation of cytosine is an important mechanism that affects the transcription of genes. Changes in global DNA methylation may also result from impaired absorption of nutrients due to intestinal damages ${ }^{(39)}$. However, we found no effect on global DNA methylation in the F1 progeny, which ranged from $7 \cdot 2$ to $7 \cdot 4 \%$ across both the groups. The level of DNA methylation in the present study was slightly lower than what has been reported previously for adult zebrafish liver, which was above $8 \%{ }^{(40)}$. In the present study, F1 larva swimming activity measurements were evaluated by investigating offspring larva activity. Movement was captured within the predefined areas, and output parameter was duration within the high-activity zone. It has been suggested that it is a disadvantage for the fish to show increased activity at this yolk-sac stage as it may negatively affect further growth and development ${ }^{(41)}$. We found no effects on larva swimming activity in the present study.

\section{Conclusion}

We found no adverse performance or reproductive effects in zebrafish fed the $B t$-maize diet for two generations, and $B t$-maize seems to be as safe and nutritious as its $n B t$-maize control. It is emphasised that parameters related to potential allergenic reactions from the Cry $1 \mathrm{Ab}$ protein were not investigated. The differences observed in contamination with mycotoxins (FB1 and AFLB1) between Bt-maize- and $n B t$-maize-containing diets may explain the effects observed on gene transcript biomarkers in pathways of the cell oxidative system and the cell cycle in fish fed the $n B t$-maize diet for two generations.

\section{Acknowledgements}

The present study was supported by the Norwegian Ministry of Fisheries and Coastal Affairs and also partially supported by a European Union Seventh Framework Programme grant (GMSAFOOD, grant no. 211820). The authors thank Øyvind Reinshol at their zebrafish research laboratory for skilled animal care and Eva Mykkeltveit, Hui-Shan Tung and Synne Wintertun for their excellent technical assistance. They also thank Kaja Skjærven for valuable discussions and input on fertilised zebrafish egg ontogeny and the DNA methylation method and Ståle Ellingsen for helping with the zebrafish swimming activity measurements. M. S., N. H. S. and G.-I. H. designed the study. M. S. designed and prepared the feeds. M. S., N. H. S., G.-I. H. and S. J. participated in the sampling. M. S. and S. J. conducted the laboratory analysis. J. G. conducted the histomorphological evaluations. M. S. and R. O. conducted the DNA methylation analysis. M. S. wrote the manuscript. All authors read and approved the final manuscript. The authors declare no conflicts of interest.

\section{References}

1. VKM (2012) Helserisikovurdering av Cry-proteiners adjuvanseffekter (Health Risk Assessment of the Adjuvant Effects of Cry Proteins). Oslo: VKM.

2. Knowles BH (1994) Mechanism of action of Bacillus thuringiensis insecticidal delta-endotoxins. Adv Insect Phys 24, $275-308$.

3. VKM (2009) Helse- og miljørisikovurdering genmodifisert maishybrid Bt11 (MIR162/GA21) fra Syngenta Crop Protection AG (EFSA/GMO/DE/2009/67) (Health and environmental assessment of Maize hybrid Bt11 (MIR162/GA21) from Syngenta Crop Protection AG). Oslo: Norwegian Scientific Committee for Food Safety. http://vkmno/dav/af6b4973b1pdf

4. Then C (2010) Risk assessment of toxins derived from Bacillus thuringiensis-synergism, efficacy, and selectivity. Environ Sci Pollut Res 17, 791-797.

5. Sanders PR, Lee TC, Groth ME, et al. (1998) Safety assessment of insect-protected corn. In Biotechnology and Safety Assessment, 2nd ed. [JA Thomas, editor]. New York, NY: Taylor Francis.

6. Sissener NH, Sanden M, Krogdahl Å, et al. (2011) Genetically modified plants as fish feed ingredients. Can J Fish Aquat Sci 68, $563-574$.

7. Sissener NH, Johannessen LE, Hevroy EM, et al. (2010) Zebrafish (Danio rerio) as a model for investigating the safety of GM feed ingredients (soya and maize); performance, stress response and uptake of dietary DNA sequences. Br J Nutr 103, 3-15.

8. Hemre GI, Sagstad A, Bakke-Mckellep AM, et al. (2007) Nutritional, physiological, and histological responses in Atlantic salmon, Salmo salar L. fed diets with genetically modified maize. Aquac Nutr 13, 186-199.

9. Sagstad A, Sanden M, Haugland O, et al. (2007) Evaluation of stress- and immune-response biomarkers in Atlantic salmon, Salmo salar L., fed different levels of genetically modified maize (Bt maize), compared with its near-isogenic parental line and a commercial suprex maize. J Fish Dis 30, 201-212.

10. Bakke AM, Gu J, Krogdahl A, et al. (2013) Effects of oral Bt-maize (MON810) exposure on growth and health parameters in normal and sensitized Atlantic salmon, Salmo salar L. Br J Nutr 109, 1408-1423.

11. Sanden M, Berntssen MHG, Krogdahl A, et al. (2005) An examination of the intestinal tract of Atlantic salmon, Salmo salar $L$., parr fed different varieties of soy and maize. J Fish Dis 28, 317-330.

12. Sanden M, Krogdahl A, Bakke-Mckellep AM, et al. (2006) Growth performance and organ development in Atlantic salmon, Salmo salar L. parr fed genetically modified (GM) soybean and maize. Aquac Nutr 12, 1-14.

13. Sissener NH, Lall SP, Sagstad A, et al. (2011) Can mycotoxins explain apparent negative effects of feeding genetically modified (GM) MON810 maize to Atlantic salmon, Salmo salar L.? Br J Nutr 106, 42-56.

14. Sanden M, Jorgensen S, Hemre GI, et al. (2012) Zebrafish (Danio rerio) as a model for investigating dietary toxic effects of deoxynivalenol contamination in aquaculture feeds. J Food Chem toxicol 50, 4441-4448.

15. Knudsen I \& Poulsen M (2007) Comparative safety testing of genetically modified foods in a 90-day rat feeding study design allowing the distinction between primary and secondary effects of the new genetic event. Regul Toxicol Pharmacol 49, 53-62.

16. van Haver E, Alink G, Barlow S, et al. (2008) Safety and nutritional assessment of GM plants and derived food and 
feed: the role of animal feeding trials. Food Chem Toxicol $\mathbf{4 6}$, S2-S70.

17. Snell C, Bernheim A, Bergé JB, et al. (2012) Assessment of the health impact of GM plant diets in long-term and multigenerational animal feeding trials: a literature review. Food Chem Toxicol 50, 1134-1148.

18. Walsh MC, Buzoianu SG, Gardiner GE, et al. (2012) Effects of short-term feeding of Bt MON810 maize on growth performance, organ morphology and function in pigs. Br J Nutr $\mathbf{1 0 7}$, $364-371$.

19. Lie O \& Lambertsen G (1991) Fatty-acid composition of glycerophospholipids in 7 tissues of cod (Gadus-Morhua), determined by combined high-performance liquid-chromatography and gas-chromatography. J Chromatogr Biomed 565, 119-129.

20. Hemre GI, Lie O, Lied E, et al. (1989) Starch as an energysource in feed for cod (Gadus-Morbua) - digestibility and retention. Aquaculture 80, 261-270.

21. Langseth W, Bernhoft A, Rundberget T, et al. (1998) Mycotoxin production and cytotoxicity of Fusarium strains isolated from Norwegian cereals. Mycopathologia 144, $103-113$.

22. Wilson JM, Bunte RM \& Carty AJ (2009) Evaluation of rapid cooling and tricaine methanesulfonate (MS222) as methods of euthanasia in zebrafish (Danio rerio). J Am Assoc Lab Anim Sci 48, 785-789.

23. Vandesompele J, De Preter K, Pattyn F, et al. (2002) Accurate normalization of real-time quantitative RT-PCR data by geometric averaging of multiple internal control genes. Genome Biol 3, 0034.1-0034.11.

24. Skjærven HK, Hamre K, Finn RN, et al. (2013) Thermal stress alters the pattern of DNA methylation and gene expression in Atlantic cod embryos. PLOS ONE. (In the Press).

25. Ramsahoye BH (2002) Measurement of genome wide DNA methylation by reversed-phase high-performance liquid chromatography. Methods 27, 156-161.

26. Jørgensen S (2012) Evaluating primary (cry1Ab) and secondary effects (deoxynivalenol) of GM maize when fed to zebrafish (Danio rerio). Masters thesis, University of Bergen.

27. Nguyen HT \& Jehle JA (2007) Quantitative analysis of the seasonal and tissue-specific expression of Cry1Ab in transgenic maize Mon810. J Plant Dis Prot 114, 82-87.

28. Murtha JM, Qi WC \& Keller ET (2003) Hematologic and serum biochemical values for zebrafish (Danio rerio). Comp Med 53, 37-41.
29. Walsh MC, Buzoianu SG, Rea MC, et al. (2012) Effects of feeding Bt MON810 maize to pigs for 110 days on peripheral immune response and digestive fate of the cry $1 \mathrm{Ab}$ gene and truncated Bt toxin. PLOS ONE 7, e36141.

30. Flachowsky G, Chesson A \& Aulrich K (2005) Animal nutrition with feeds from genetically modified plants. Arch Anim Nutr 59, 1-40.

31. Carlson DB, Williams DE, Spitsbergen JM, et al. (2001) Fumonisin B-1 promotes aflatoxin B-1 and $N$-methyl- $N^{\prime}$ nitro-nitrosoguanidine-initiated liver tumors in rainbow trout. Toxicol Appl Pharmacol 172, 29-36.

32. Lee DJ, Wales JH, Ayres JL, et al. (1968) Synergism between cyclopropenoid fatty acids and chemical carcinogens in rainbow trout (Salmo gairdneri). Cancer Res 28, 2312.

33. Pedrosa K \& Borutova R (2011) Synergistic effects of mycotoxins discussed. Feedstuffs 83, 1-3.

34. Yoo HS, Norred WP, Showker J, et al. (1996) Elevated sphingoid bases and complex sphingolipid depletion as contributing factors in fumonisin-induced cytotoxicity. Toxicol Appl Pharmacol 138, 211-218.

35. Santacroce MP, Conversano MC, Casalino E, et al. (2008) Aflatoxins in aquatic species: metabolism, toxicity and perspectives. Rev Fish Biol Fisheries 18, 99-130.

36. Hansen AC, Olsvik P and Hemre GI (2011) Biomarkers for cobalamin deficiency in Zebrafish, Danio rerio. Genomics in Aquaculture International Symposium, 14-17 September, Heraklion, Crete, Greece.

37. Gomez-Requeni P, Conceicao LEC, Jordal AEO, et al. (2010) A reference growth curve for nutritional experiments in zebrafish (Danio rerio) and changes in whole body proteome during development. Fish Physiol Biochem 36, 1199-1215.

38. Brake DG, Thaler R \& Evenson DP (2004) Evaluation of $\mathrm{Bt}$ (Bacillus thuringiensis) corn on mouse testicular development by dual parameter flow cytometry. J Agric Food Chem 52, 2097-2102.

39. Hunder G, Schümann K, Strugala G, et al. (1991) Influence of subchronic exposure to low dietary deoxynivalenol, a trichothecene mycotoxin, on intestinal absorption of nutrients in mice. Food Chem Toxicol 29, 809-814.

40. Mirbahai L, Williams T, Zhan H, et al. (2011) Comprehensive profiling of zebrafish hepatic proximal promoter $\mathrm{CpG}$ island methylation and its modification during chemical carcinogenesis. BMC Genomics 12, 3.

41. Penglase SJ, Hamre K \& Ellingsen S (2011) Selenium nutrition in zebrafish (Danio rerio). 3rd Zebrafish Network Norway Meeting, 3-6 November, Bergen, Norway. 